\title{
Politics, Progress, and Parliament in 2018: \\ Can Lebanese Women \\ Make Headway?
}

Catherine Batruni \& Marcus Hallinan 


\section{SUMMARY OF KEY FINDINGS}

Lebanon may witness a remarkable rise in the number of women serving in Parliament come May 2018 due to initiatives from women's groups, "civil society" activists, and the substantial number of female candidates - 113 at the start of the election period. However, as this briefing paper shows, Lebanese women continue to face numerous challenges in entering government. The new electoral law passed in June 2017 does not provide women with equal opportunity to be elected, and it is yet to be seen whether it will increase female representation in Parliament. Nevertheless, the historic number of female candidates running in this election demonstrates that women are more determined than ever to increase their presence in Lebanese politics.

Catherine Batruni is a doctoral candidate in Modern Middle Eastern History at the American University of Beirut. She is currently writing her thesis on the role of an American women's college in Beirut in the advancement of Lebanese women in the 20th century. Batruni additionally conducts research on Lebanese women's participation in public politics, and has presented papers on this subject at various international conferences.

Marcus Hallinan is an independent research consultant with a Master of Arts in Political Studies from the American University of Beirut. Hallinan specialises in the Lebanese political system; non-state armed actors such as Al-Qaeda, the so-called Islamic State, and Hezbollah; and American foreign policy in the Middle East. He is currently consulting for the Sanaa Centre for Strategic Studies on the war in Yemen. 


\section{Women in politics in Lebanon: Navigating the "patriarchal bargain"}

Lebanese women have achieved significant progress in the educational ${ }^{3}$ and economic ${ }^{4}$ spheres, but have been far less successful in the political realm. ${ }^{5}$ For most women who have entered political office, their accession can be attributed to a lack of male heirs to fill the seat of a deceased male relative. ${ }^{6}$ The primary factors contributing to the dearth of female participation in Lebanese politics derive from the structure

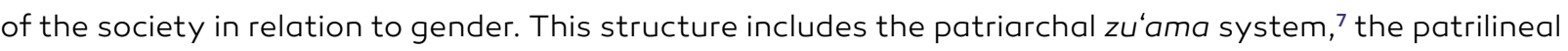
kinship basis of the society, ${ }^{8}$ the sectarian system of government, the power of religious institutions, ${ }^{9}$ and the legacy of French colonialism. ${ }^{10}$

Lebanon will elect a new Parliament on 6 May 2018, nearly a decade after its last Parliamentary elections. ${ }^{11}$ The new electoral law passed in June 2017 introduced a "proportional" voting system and redrew electoral districts. ${ }^{12}$ As of mid-March 2018, 113 women were registered to run for Parliament, a stunning increase from the 2009 elections, where 12 women ran and four were elected. These 113 women have various affiliations and are largely non-traditional in profile. The majority do not come from political dynasties and 103 of them are running independently or as "civil society" candidates. ${ }^{13}$

This context prompts the following questions:

- Will this election put Lebanon on the road to greater female representation in Parliament, or will former warlords and men from political dynasties continue to dominate the government?

- Will elected women come from traditional political parties and families, or will new faces emerge?

- Does the new law provide a space for women, particularly those unaffiliated with mainstream politics, or does it merely reinforce the status quo?

- Finally, have new "civil society" coalitions challenged dominant confessional and gender dynamics?

This policy brief argues that while the historic number of female candidates seems promising in expanding Lebanese women's political participation, this phenomenon is primarily a result of initiatives by individual women, women's groups, and other "civil society" initiatives, rather than institutional encouragement or structural changes within the government. Furthermore, while it is difficult to predict whether or not the new electoral law will lead to an increase in female representation in Parliament, it is clear from the outset that the new law does not provide women with equal opportunity to be elected. There is already a glaring mismatch in place between equality of opportunity and equality of result. Additionally, mainstream political parties have not aided women in this matter. This has led most female candidates to align themselves with new "civil society" groups attempting to challenge the confessional and gendered status quo by creating coalitions opposing establishment sectarian parties, and by nominating women to their ranks.

\section{The New Electoral Law: Quotas for sects - but not for women}

The new electoral law includes changes to electoral districts and two distinctly new aspects: "proportional" representation and the choice of a "preferred" candidate. Citizens do not elect candidates as individuals, but have to cast their vote for a list of candidates in their district, and then cast one preferential vote for a candidate from the list they have chosen. The number of seats a list can win depends on the electoral quotient ${ }^{14}$ and the number of votes a list obtains. The total amount of votes won by a list is divided by the electoral quotient which will determine the specific number of seats a list will be awarded. Following this, candidates in a district will be chosen according to the most preferential votes received. Once a confession's seat(s) or the number of seats won by a list are exhausted, the remaining candidates from that sect 


\section{Figure 1: Distribution of 2018 Lebanese parliamentary candidates by gender, before and after list deadline}

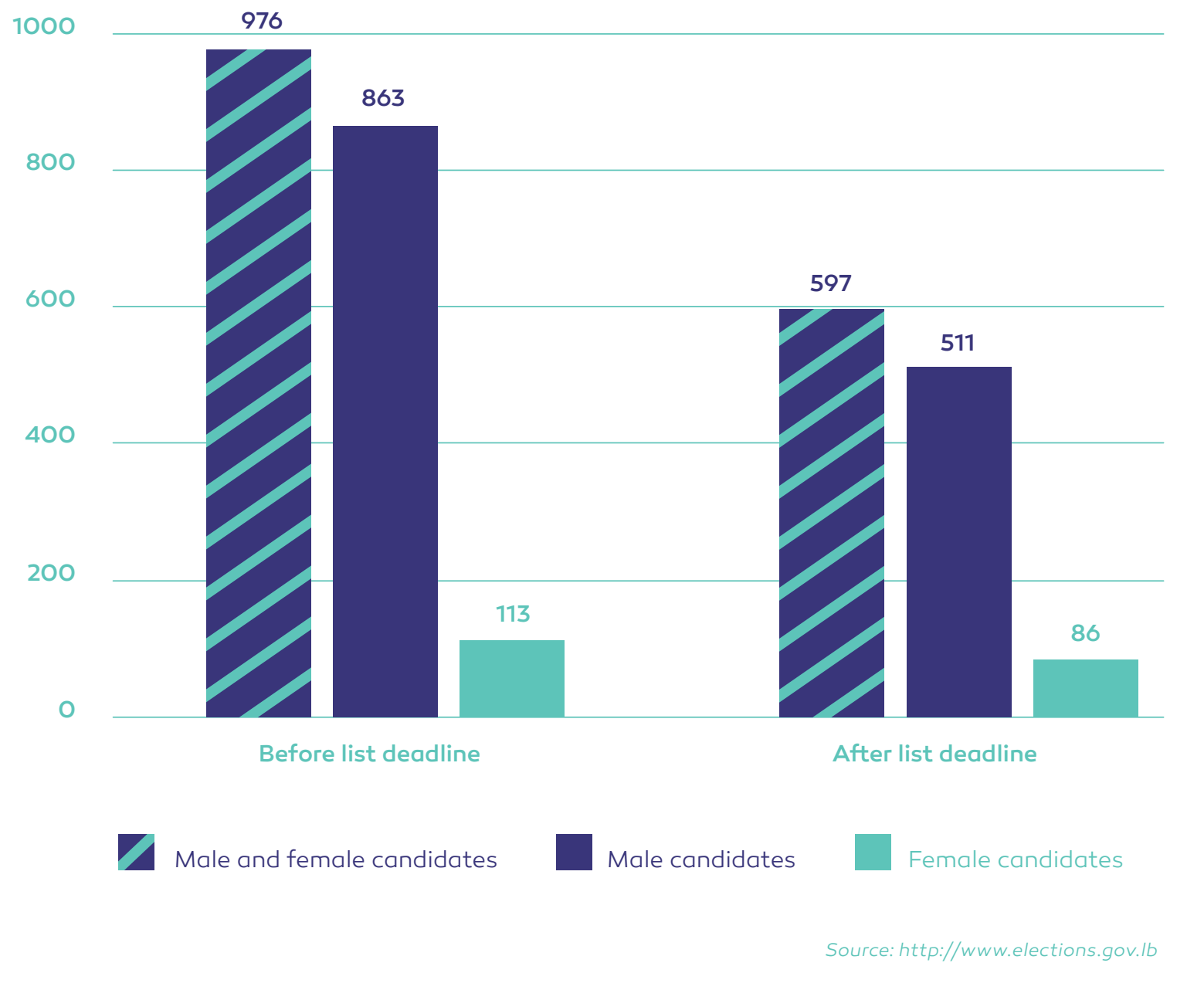

or list are ineligible. Thus, a candidate who receives a higher number of preferential votes can lose to a candidate who accumulates less votes, simply due to the seat allocation per sect. Hardly any aspect of this new law results in equitable competition among candidates.

Moreover, the law rearranges Lebanon into 15 electoral constituencies made up of 27 qadaa, or sub-districts. ${ }^{15}$ This gerrymandering divides sects into separate districts, rather than creating districts with mixed constituencies, ${ }^{16}$ which will keep smaller districts with stronger sectarian affinities and clientelist systems intact and more powerful. This would appear to harm independent candidates, as voters may be more likely to cast their preferential vote for a member of their own sect or party. ${ }^{17}$ This assumption is based on the history of entrenched primordial loyalties in the country and it seems logical that new candidates without a loyal base will struggle to acquire as many votes. Since the majority of the 113 female candidates are running independently and do not have an established political base, it is unlikely that they will be able to win a large number of seats in this new voting system, even though women are running in all 15 districts.

Candidates were required to form electoral lists by late March 2018 to remain eligible. A total of 976 candidates were originally registered, and 113 of them were women. ${ }^{18}$ Due to the conditions of the new electoral law, candidates who were unable to join lists were disqualified. At the time of writing, 597 candidates remain after the withdrawal deadline with 379 people - 27 women and 352 men - having dropped out (Figure 1). ${ }^{19}$ 
Before a single vote has been cast, the law has already denied the opportunity to almost 1/4 of women who had presented their candidacy. As such, the new law does not facilitate access to Parliament, particularly for female candidates, as it has already eliminated many women who could not join lists. There are 511 men and 86 women still running, with $41 \%$ of men and $24 \%$ of women withdrawing.

Despite $24 \%$ percent of women withdrawing, a slight majority of the registered lists have female candidates. Out of 77 lists, there are 48 lists (62.3\%) with at least one woman, and 28 lists (36.4\%) with no women (Figure 2). Only one list - Nisā' Akkar - is entirely composed of women. ${ }^{20}$ Nisā' Akkar is the only list that is radically challenging traditional gender dynamics on the Lebanese political scene, not only by excluding men from their list but also by aiming for women to fill half of parliamentary seats. ${ }^{21}$

Had a gender quota been adopted, it might have encouraged female-only lists to be formed, and have guaranteed equality of opportunity for women. Lebanon uses religious quotas for sects in Parliament, but has not instituted gender quotas for this election, despite active campaigning by women's groups. ${ }^{22}$ The Kataeb party introduced a bill to Parliament that proposed a 1/3 gender quota for parliamentary seats, but this bill was not adopted. ${ }^{23}$ One of the most vocal opponents of the bill was Hezbollah, who explicitly articulated opposition to having women in decision-making positions. ${ }^{24}$ Regardless of official positions on quotas, all mainstream political parties failed to nominate significant numbers of female candidates for the 2018 elections. An example showcasing this dissonance was when Lara Saade, Head of Public Policy and Legislation for the Kataeb party, wanted to run for the 2018 election and expected a nomination. When the

\section{Figure 2: Distribution of female candidates across 77 lists}

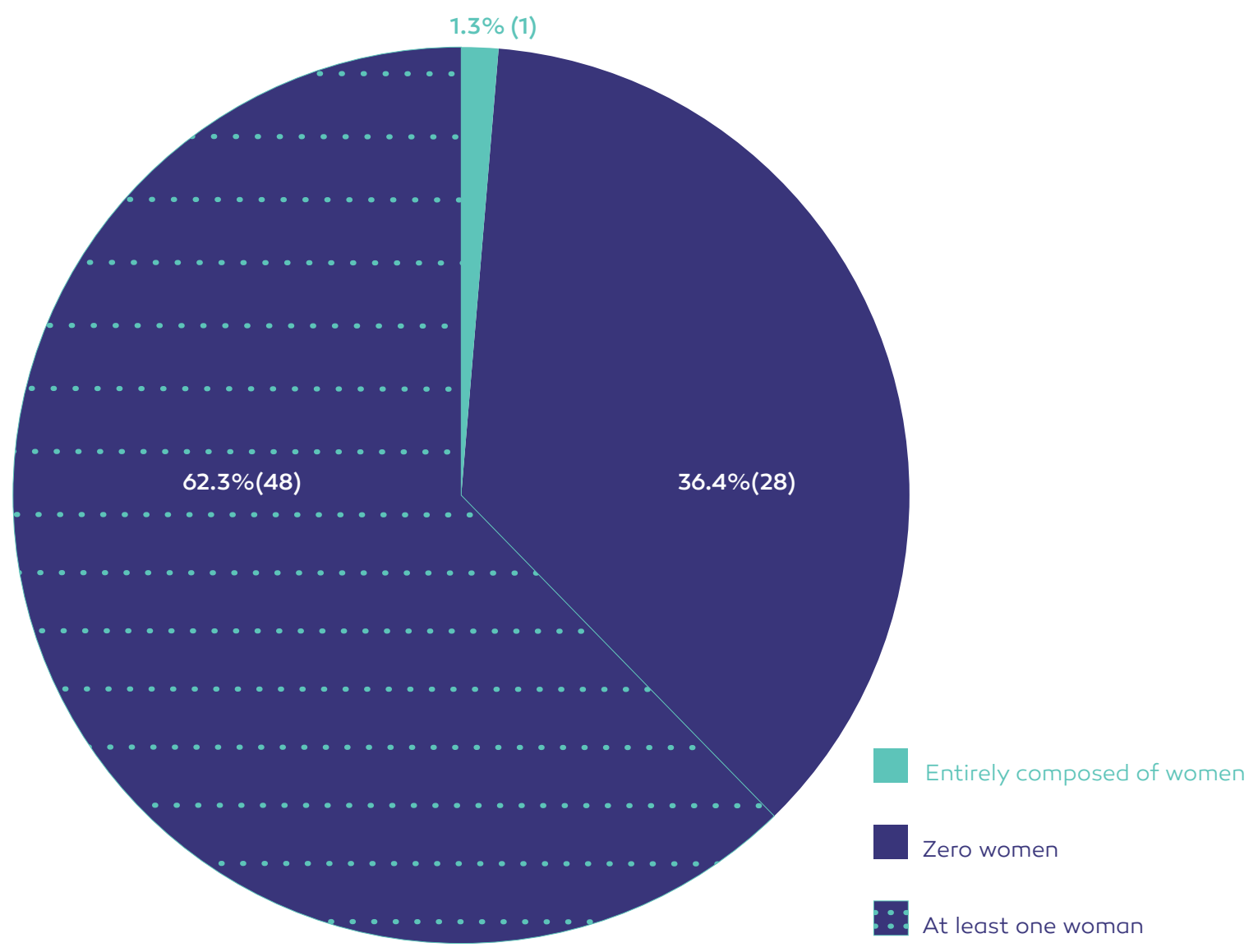


choice came down to Saade or another Kataeb member, Elie Marouni, the party chose Marouni over her. ${ }^{25}$ The fact that Marouni publicly stated last year that women who are raped are at fault ${ }^{26}$ did not prevent the allegedly pro-gender quota Kataeb from nominating him over a qualified woman.

\section{Women in traditional parties: Politics of dissonance}

In July 2012, male and female representatives from Lebanese political parties participated in workshops run by the Unit of Women's Affairs under the Ministry of Social Affairs to expand women's presence in the government. ${ }^{27}$ Despite this, political parties have only increased their number of female candidates by a small margin (Figure 3). In Lebanon's 2018 elections, four of the Future Movement's 37 candidates are women; The Free Patriotic Movement is putting forward two women from 46 candidates; The Kataeb nominated two women out of 17 candidates; Amal has one woman from a total of 16 candidates, and neither the Progressive Socialist Party nor Hezbollah have female candidates among 10 and 13 candidates respectively. ${ }^{28}$ Only $9 \%$ of female candidates in this election have been nominated by establishment political parties. ${ }^{29}$ This confirms that a gender quota is a more realistic way to increase the number of women in Parliamentand compel political parties to nominate more women. However, sceptics of gender quotas, such as Neamat Badreddine, who is running for a Shia seat in Beirut II, posit that establishment party leaders would simply "insert female family and friends" if forced to adhere to a quota. ${ }^{30}$

An unexpected, major finding of this paper is that women do play prominent decision-making roles in some of the establishment political parties. However, political parties seem uninterested in nominating women to Parliament in particular. For instance, seven women are employed in the politburo of Future Movement, ${ }^{31}$ while the Secretaries General of both the Free Patriotic Movement ${ }^{32}$ and the Lebanese Forces ${ }^{33}$ are women. Most of the mainstream political parties have women's committees, pointing to the seeming openness of these groups in incorporating women, though it is unclear what precise role they expect women to play.

\section{From family and financial challenges...}

Further constraints on women's participation in politics are family pressure and financial considerations. Surprisingly, 14 out of the 15 female candidates interviewed, declared that their families were extremely supportive of their political aspirations. This indicates that family support is important in women's decision to run for public office. Financial challenges are a further complicating factor. Out of 15 candidates, 13 were struggling to finance their campaigns. Ali Sleem, from the Lebanese Association for Democratic Elections (LADE), ${ }^{34}$ stated: "It's harder for women in the preferential vote because of the high expenditure ceiling. Each candidate has the option and right to have expenses up to USD 200,000, which is an amount of money generally only accessible to members of established parties or those who are independently wealthy. ${ }^{35}$ Each candidate's ceiling is very high." 36 Financial factors marginalise women, newcomers, and people who are not extremely wealthy, and bolster the current system by reinforcing the positions of existing leaders with sizable economic capital.

\section{...To challenging the overall patriarchal structures}

Women's political empowerment and personal status laws are inextricably linked. Indeed, many female candidates appear eager to change personal status laws in the hands of the clergy and that dictate women's rights in marriage, divorce, child custody, and inheritance. Nayla Geagea, who was running in Beirut II for a Shia seat but withdrew her candidacy, underscored the unjust nature of personal status 
laws by pointing out that they allow "some Muslim women to be divorced over WhatsApp, while some Christian women remain trapped in abusive or unhappy marriages." 37 Candidate Zoya Rouhana, running in Chouf-Aley for a Greek Orthodox seat, explained that her main objectives were to pass a comprehensive law dealing with all forms of violence that women face, in addition to a mandatory civil law for personal status that would eliminate the control of confessional courts over women's private lives. Rouhana believes that "the mentality and culture of the Lebanese cannot be changed. Reforming the laws is a much simpler solution than changing the patriarchal culture." 38 As Rouhana mentioned, patriarchal culture is a major obstacle hindering women from being active in public politics, and is embedded within all social structures in Lebanon. ${ }^{39}$

Figure 3: Female candidates nominated by Lebanon's major parties in 2018

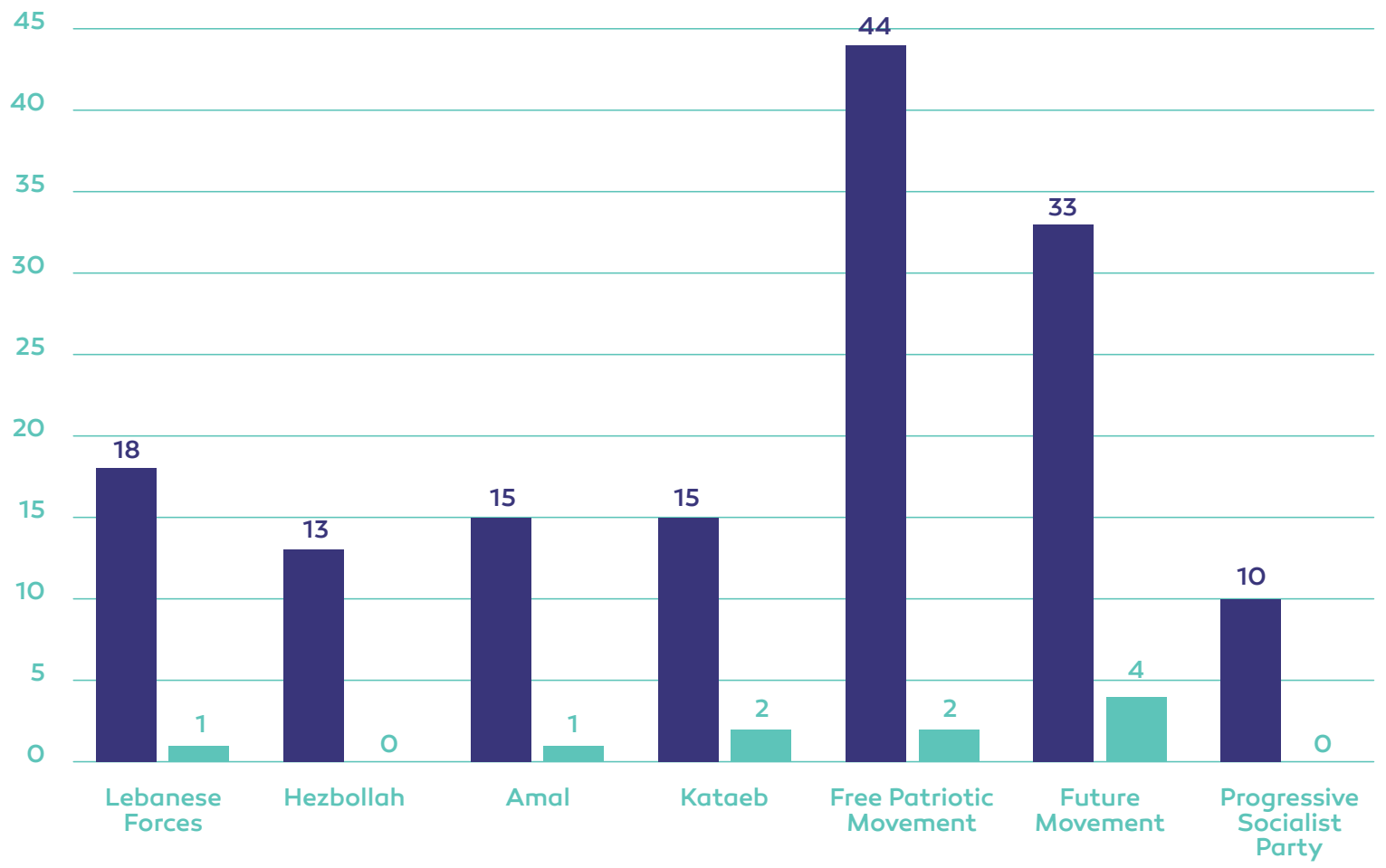

Male candidates

Female candidates 


\section{Advancing women's political participation in Lebanon}

\section{Basic reforms in the next electoral law}

The most crucial electoral reform that should be undertaken is the passing of a new electoral law before the next election that will allow candidates to run as individuals without having to join a list. The list system has clearly restricted women in this election, as $24 \%$ of female candidates were unable to join one.

Moreover, the Lebanese government should waive the USD 5,000 registration fee for candidates in order to incentivise both women and men from non-elite backgrounds to run for public office, and to create more equal opportunities among candidates, regardless of their gender.

\section{Traditional parties need to take immediate steps to encourage women's formal and effective participation to politics}

Traditional parties need to be more open to women - notably by the adoption of a gender quota. A major finding in this paper is that the majority of female candidates are unrelated to mainstream parties and have joined new coalitions instead; hence, women's participation needs to be expanded within traditional political parties. An expedient step that can be taken before the next election is to require either a $30 \%$ or $50 \%$ gender quota for both political party candidates and parliamentary seats. This law would encourage more women to run, knowing that they are guaranteed seats, while simultaneously forcing political parties to nominate female candidates. Furthermore, a gender quota will normalise the image of women in politics and dissolve the popular stereotype that politics is a male domain.

\section{Economic and labour reforms: unlocking women's full political potential}

Economic reforms are equally urgent. Providing more employment opportunities for women and increasing their presence from merely $25 \%$ of Lebanon's labour force ${ }^{40}$ will be a major gain for women's autonomy and economic independence. Women considering running for Parliament who are concerned about finances should utilise social media to subvert the expensive cost of promoting oneself on television, as well as to organise and promote campaigns, workshops, and events.

\section{The power of collaboration: united alternative campaigns}

Campaigns and coalitions emerging from "civil society" organisations should collaborate with other actors who share the same values and objectives, and then campaign effectively. "Civil society" groups have lacked collaboration in this election, and their presence is not as strong as that of female candidates. Women are running in all 15 districts, but "civil society" groups are only running in only nine districts. Although this is slightly more than half of the districts, more serious collaboration could have resulted in a civil society presence in all 15 districts. This would further challenge traditional sectarian parties. As articulated by candidate Joumana Haddad, running for the Minorities seat in Beirut "civil society needs to present a united front because they're the minority challenging a very traditional system." 41 A strong coalition of non-traditional political actors would increase chances to challenge political feudalism and the patron-client system in order to improve political rotation in Lebanese polity.

\section{Legal reforms towards full equality and citizenship}

Lebanese women face myriad obstacles in cultivating a significant presence in the political sphere. There is no single factor that can explain the shortage of women in public politics and therefore no single solution. Women are greatly disadvantaged in all realms of the Lebanese legal system and "the regulation of sexual 
difference is not limited to the arena of personal status, but rather is the constitutive knot at the centre of civil, criminal, and procedural law in Lebanon." 42

To encourage more Lebanese women into Parliament, they must first become full and equal citizens. All Lebanese, regardless of sect or gender, should enjoy the same rights under civil laws. This will render women equal citizens to men, which would result in an increased presence in the economic and political sector. Lebanese women cannot be expected to fully participate in society when they are unequal with men, as well as amongst each other. This would entail reforming the following social and legal obstructions that subjugate women: personal status laws, the nationality law, criminal laws that deal with gender-based violence, and electoral laws.

Ending the Lebanese confessional system's control over citizens' lives is by far the most urgent issue in regards to women, and the most difficult, as this is the very configuration of the Lebanese social and political order. Substantial reforms in the patriarchal laws that manage women's affairs in marriage, divorce, inheritance, and child custody could also considerably improve women's conditions. Lebanese politicians have proven time and again that they do not prioritise women's rights. Preventing women from gaining more rights placates religious elites, who hold significant jurisdiction over women's personal status and social mobility. Based on analysis of the 2018 electoral campaign, it appears that the most effective way to achieve this is to actively lobby personal status courts and politicians via popular campaigns from local women's rights groups. Advocacy is a powerful weapon in this case as it mobilises women, pressures the government, and exposes politicians and political parties who vote against women's rights. It is also recommended that the government addresses gender-based violence through criminalising sexual harassment and marital rape.

Another urgent legal reform is for all Lebanese women to be able to pass on their citizenship to their children. The current law discriminates against women by depriving them of this right. If a child can only become Lebanese through a father, then citizenship is inherently male. For women to become full citizens, it is imperative that they are given this right. Women's groups should continue to politicise the issue until this unjust law is modified appropriately.

Lastly, women's political participation cannot be considered separately from legal, economic, and social reform. The interdependence of numerous patriarchal and patrilineal legal, political, economic, and social systems in Lebanon make it extremely challenging for women to redefine or defy these structures. Structural change would result in gender equality, but women should not simply wait for this to transpire. Until it does, women should continue to navigate the "patriarchal bargain." 43 
1 This briefing paper is published in the frame of the call: "New on The Scene, Can Emerging Political Actors and Women Make Headway in Lebanon's 2018 Parliamentary Elections?". For a thorough discussion of "new" and "civil society actors" participation in Lebanon's 2018 Parliamentary elections, see: Zeina el-Helou, "Lebanon's 2018 Elections: An Opportunity for "New" Political Actors" Civil Society Knowledge Centre, Lebanon Support, Beirut, April 2018.

2 Deniz Kandiyoti, "Bargaining With Patriarchy," Gender and Society Vol. 2 (3), September 1988, p. 274-290. In the patriarchal bargain, women work within the constraints of a patriarchal system to maximise options and benefits.

3 Though Lebanon ranks low in world averages of secondary education for both genders, women only have a slightly lower literacy rate than men, and men and women tend to have fairly equal secondary education enrolment numbers. Women make up half of all university students in Lebanon. William Avis, "Gender Equality and Women's Empowerment in Lebanon," DFID Helpdesk Report, August 2017, p.12.

4 Lebanese women comprise approximately $25 \%$ of the labour force. "The Women of Lebanon in Statistics - 50\% of the Population, $25 \%$ of the Labor Force and $3 \%$ of Politicians," The Monthly, 6 May 2015, available at: http:// monthlymagazine.com/articledesc_1722_[ last accessed 7 April 2018].

5 Currently, only four seats in Lebanon's 128-member Parliament are held by women, all of whom hail from political families: Bahia Hariri, Strida Geagea, Nayla Tueni, and Gilberte Zwein. Other government offices are overwhelmingly concentrated in the hands of men.
6 Lamia Rustum Shehadeh, "Women Before the War," in Lamia Rustum Shehadeh Gainesville (ed.), Women and War in Lebanon, Florida, University Press of Florida, 1999, p. 33-34.

7 Zu'ama is the plural of za'ìm, a community leader or strongman who provides services in exchange for loyalty. Nizar Hamzeh, "Clientelism, Lebanon: Roots and Trends," Middle Eastern Studies, Vol. 37 (3), July 2001, p. 167-178.

8 Suad Joseph, "Descent of the Nation: Kinship and Citizenship in Lebanon," Citizenship Studies, Vol. 3 (3), 1999, p. 295-318.

9 Lamia Rustum Shehadeh, "Gender-Relevant Legal Change in Lebanon," Feminist Formations, Vol. 22 (3), 2010, p. 210-228.

10 Elizabeth Thompson, Colonial Citizens: Republican Rights, Paternal Privilege, and Gender in French Syria and Lebanon, New York, Columbia University Press, 2000.

11 Youssef Diab, "Lebanese Parliament Heads to Toward a Third Term Extension," Ashara al-Awsat English, 12 April 2017, available at: https://eng-archive.aawsat.com/youssefdiab/news-middle-east/ lebanese-parliament-heads-toward-third-term-extension [last accessed 7 April 2018]. The length of one parliamentary term is four years. Parliamentary elections should have been held in June 2013, but were postponed three times. The parliament illegally extended its own mandate in 2014 until 2018, citing security concerns regarding the war in Syria.

12 Lebanon's most recent parliamentary elections were held in 2009. While parliament holds a four-year mandate, subsequent elections were cancelled several times. The main justification for these extensions was the need to reach an agreement from all parties over electoral reform.
Over the years since 2009 , lawmakers have gone back and forth on this reform. The previous electoral system was criticised for not being representative. In 2016, the Parliament elected Michel Aoun President as part of a power-sharing deal that placed Saad al-Hariri as prime minister. Not long into his presidency, Aoun announced that he would not allow for yet another Parliamentary extension. After six months of negotiations in closed doors meetings, the new law was announced in June 2017 law and set a timeline for the first round of Parliamentary elections in nine years to take place in May 2018.

13 Civil society can be fertile ground for the emergence of political outsider candidates to run within a system that generally bolsters the grip of elite political families on the government. In Lebanon, civil society has functioned as a mechanism to hold the political sphere accountable to the electorate. The emergence of civil society actors as political actors is a new and important development in a country where political positions are often recycled among male family members.

14 The electoral quotient is the total number of votes cast in a district divided by the number of seats available in that district.

15 During parliamentary elections in the previous majoritarian system, political parties formed alliances to create lists of candidates. The party would choose the candidates, and members of that party would vote for the list of candidates their party told them to. This way of doing things was not codified into law and technically a candidate could run without being part of a list, but in practice, most voters would choose entire lists. Whichever list accumulated the most votes would win all the seats of that district, with candidates allocated by sectarian quota. This meant that even if the list in second place received a majority of the 
votes, none of their candidates would make it to Parliament.

16 "Lebanese Electoral Law 2017: Full Text in English," The Daily Star, 3 April 2018, available at: http://www.dailystar.com.lb/ News/Lebanon-News/2017/ Jul-07/411988-lebaneseelectoral-law-2017-full-textin-english.ashx [last accessed 3 April 2018].

17 Bachir el Khoury, “Lebanon's Civil Society Groups Gear Up for 2018 Elections,"

al-Monitor, 19 June 2017, available at: https://www. al-monitor.com/pulse/originals/2017/06/lebanon-civil-society-non-partisans-prepare-for-elections.html [last accessed 7 April 2018]

18 These statistics are available in various PDF documents on Lebanese Elections Website, Official Website, overview available at: https://bit ly/2H2pVW3 [last accessed 1 April 2018]. Although the official number of female candidates announced by the Ministry of Interior and Municipalities on 7 March 2018 amounted to 111 , the total number of female candidates was later revised to 113 (as confirmed by phone call with the Ministry of Interior and Municipalities on 22 March 2018).

19 Ibid.

20 Lebanese Elections Website, Official Website, overview available at: https://bit. ly/2uwGdAZ [last accessed 1 April 2018].

21 Najla Hamoud, "Nisā' Akkar": We Hope to be Half of Parliament" (Arabic), al-Akhbar, 10 March 2018, available at: https://al-akhbar.com/Politics/245915 [last accessed 7 April 2018]

22 "'Half of Society, Half of Parliament' - Lebanese Women Campaign for More Political Power," The National, 21 January 2018, available at: https://www.thenational. ae/world/half-of-society-half-of-parliament-lebanese-women-campaign-for-more-political-power-1.697205 [last accessed 7 April 2018].

23 "Saade: Kataeb Party Holding on to Women Quota Demand," Kataeb Website, 8 March 2017, available at: http://www kataeb.org/local/2017/03/08/ saade-kataeb-party-holding-onto-women-quota-demand [last accessed 7 April 2018]

24 "Lebanese Women Look for Greater Role in Parliament Elections," Gulf News, 21 January 2018, available at: http://gulfnews.com/news/ mena/lebanon/lebanese-women-look-for-greater-role-inparliament-elections-1.2160316 [last accessed 7 April 2018].

25 Interview by the authors, Lara Saade, Beirut, 15 March 2018.

26 "Lebanese MP Elie Marouni Blames Lebanese Women For Getting Raped," A Separate State of Mind, 9 August 2016, available at: https://stateofmind13.com/2016/09/09/ lebanese-mp-elie-marouniblames-lebanese-women-forgetting-raped/elie-marouni/\#main [last accessed 7 April 2018].

27 Tanya Henderson, Camille Nelson, \& Zeina Chemali, “Increasing Women's Political Participation in Lebanon: Reflections on Hurdles, Opportunities and Hope," Journal of Politics and Law Vol. 8 (4), 2015, p. 233.

28 "\#Elections2018: Female Candidates on Lebanon's Major Political Parties' List," Blog Baladi, 18 March 2018, available at: http://blogbaladi.com/ elections2018-female-candidates-on-lebanons-major-political-parties-lists/

29 Lebanese Elections Website, Official Website, overview available at: https://bit.ly/2H2pVW3 [last accessed 1 April 2018]
30 Interview by the authors, Neamat Badreddine, Beirut, 13 March 2018.

31 Interview by the authors, Nawal Mudallali, Beirut, 13 March 2018.

32 Martine Najem is the Secretary General of the Free Patriotic Movement. Interview by the authors, Martine Najem, Beirut, 21 March 2018.

33 "Sarkis, First Female Secretary-General," 21 Oct. 2016, available at: https:// www.lebanese-forces. com/2016/10/21/chantalsarkis-2/ [last accessed 7 April 2018].

34 Founded by civil society activists in 1996, LADE has played a pioneering role in Lebanon by monitoring elections, and carrying out initiatives to guarantee free, fair, and transparent elections. See http://www.lade.org.lb [last accessed 7 April 2018]

35 Article 61 of the new law states: The ceiling of the maximum amount that each candidate may spend during the campaign period shall be determined according to the following: A fixed section of LL150 million (USD 99,240), plus a section subject to change that is linked to the number of voters in a sizable electoral district in which he is elected to the amount of LL5,000 for each registered voter in the electoral lists in the large constituency. The ceiling of the electoral spending of the list is a fixed amount of LL15O million for each candidate. This ceiling can be reconsidered at the opening of the campaign period in the light of economic conditions, by a decree adopted by the Council of Ministers on the proposal of the Interior Minister and after consultation with the Commission.

36 Interview by the authors, Ali Sleem, Beirut, 14 March 2018.

37 Interview by the authors, Nayla Geagea, Beirut, 10 March 2018. Geagea had to drop out due to 
disagreements she had with candidates who were supposed to run on a list with her. The interview for this briefing paper was conducted before Geagea's withdrawal. Geagea elaborates upon the reasons for her withdrawal on a televised interview on LBCl. Interview by Dima Sadek, Nayla Geagea (Arabic), Nharkom Said, 28 March 2018, available at: https://www. lbcgroup.tv/watch/37981/nayla-geagea-emad-bazzi-raghida-dergham/en [last accessed 7 April 2018]. Geagea states that she intends to run again in four years.

38 Interview by the authors, Zoya Rouhana, Beirut, 15 March 2018.

39 Suad Joseph, op.cit., 1999 p. 295-318.

40 Lebanese women comprise approximately $25 \%$ of the labour force. "The Women of Lebanon in Statistics $-50 \%$ of the Population, $25 \%$ of the Labour Force and $3 \%$ of Politicians," op. cit.

41 Interview by the authors Joumana Haddad, Beirut, 16 March 2018.

42 Maya Mikdashi, "Sex and Sectarianism: The Legal Architecture of Lebanese Citizenship," Comparative Studies of South Asia, Africa and the Middle East Vol. 34 (2), 2014, p.281.

43 Deniz Kandiyoti, op. cit., p. 274-290 


\section{Team}

Catherine Batruni \& Marcus Hallinan, Researchers and Lebanon Support consultants

Amreesha Jagarnathsingh, Research \& Project Officer

Mia BouKhaled, Research \& Project Officer

Sarah EIMasry, Gender Researcher

Léa Yammine, Director of Publications

Marie-Noëlle AbiYaghi, Head of Research

\section{Copy Editor}

Alex Ray

\section{Design \& Layout}

Nayla Yehia

Léa Yammine

Lebanon Support would like to thank the following colleagues for the inputs and discussions that contributed to the development of this briefing paper:

Doreen Khoury, Miriam Younes.

Women Empowered for Leadership (WE4L) is a programme by Hivos with local partners in five countries: Malawi, Zambia, Zimbabwe, Jordan and Lebanon.

The views expressed in this publication are solely those of the author(s) and do not necessarily reflect the views of Lebanon Support nor its partners.

Lebanon Support (c) Beirut, April 2018.

No part of this publication may be reproduced, distributed, or transmitted in any form or by any means, including photocopying, recording, or other electronic or mechanical methods, without the prior written permission of the publisher, except in the case of brief quotations and referencing in critical reviews and articles, and certain other noncommercial uses permitted by copyright law. 